\title{
Influence of stimulus frequency on blockade induced by pancuronium and rocuronium. Study on rats phrenic nerve-diaphragm preparation ${ }^{1}$
}

\author{
Influência da freqüência de estímulos no bloqueio neuromuscular produzido pelo \\ pancurônio e rocurônio. Estudo em preparação nervo frênico-diafragma de ratos
}

\author{
Angélica de Fátima de Assunção Braga², Derli Conceição Munoz ${ }^{3}$, Franklin Sarmento da Silva Braga², Daniele \\ Ribeiro de Araujo ${ }^{4}$, Glória Maria Braga Potérioº ${ }^{2}$ Mario Mantovani ${ }^{5}$ \\ 1. ResearchperformedatLaboratoryofNeuromuscularJunction,DepartmentofPharmacology, StateUniversityofCampinas(UNICAMP), SãoPaulo,Brazil. \\ 2. $\mathrm{PhD}$, Associate Professor, Department of Anesthesiology, Faculty of Medical Sciences, UNICAMP, São Paulo, Brazil. \\ 3. PhD, Department of Anesthesiology, Faculty of Medical Sciences, UNICAMP, São Paulo, Brazil. \\ 4. PhD, Department of Biochemistry, Institute of Biology, UNICAMP, São Paulo, Brazil. \\ 5. PhD, Full Professor, Department of Surgery, Faculty of Medical Sciences, UNICAMP, São Paulo, Brazil.
}

\begin{abstract}
Purpose: To evaluate the influence of two stimulation frequencies on the installation of neuromuscular blockade produced by pancuronium and rocuronium on the rat diaphragm. Methods: Diaphragms were submitted to an indirect frequency stimulation of 0.1 and $1 \mathrm{~Hz}$ (Groups I and II, respectively). Subgroups were formed $(\mathrm{n}=5)$ according to the neuromuscular blocker employed (pancuronium- $2 \mu \mathrm{g} / \mathrm{ml}$ and rocuronium $-4 \mu \mathrm{g} / \mathrm{ml}$ ). The twitch height depression was evaluated at 5,15 and 30 minutes after adding the neuromuscular blocker. Results: The decrease in twitch height was greater $(p<0.01)$ with a frequency of $1 \mathrm{~Hz}$ at all time periods studied both in preparations that are blocked with pancuronium and in those that are blocked with rocuronium. Conclusion: The frequency of stimulation interferes significantly with the installation of neuromuscular blockade produced by pancuronium and rocuronium, since the reduction in amplitude of the rat diaphragm response was greater for $1 \mathrm{~Hz}$ frequencies, at all periods studied.
\end{abstract}

Key words: Neuromuscular nondepolarizing agents. Neuromuscular Blocking Agents . Phrenic Nerve. Diaphragm. Electric Stimulation. Rats.

\section{RESUMO}

Objetivo: Avaliar a influência de duas freqüências de estimulação na instalação do bloqueio neuromuscular induzido por pancurônio e rocurônio em diafragma de ratos. Métodos: Os diafragmas foram submetidos a uma freqüência de estimulação indireta de 0.1 e $1 \mathrm{~Hz}$ (Grupos I e II, respectivamente). Os animais foram divididos em subgrupos ( $\mathrm{n}=5$ ) de acordo com o bloqueador neuromuscular a ser utilizado (pancurônio- $2 \mu \mathrm{g} / \mathrm{mL}$ e rocurônio- $4 \mu \mathrm{g} / \mathrm{mL}$ ). A amplitude das respostas musculares foi avaliada 5, 15 e 30 minutos após a adição do bloqueador neuromuscular à preparação. Results: A redução na intensidade da contração foi maior $(p<0.01)$ com a freqüência de $1 \mathrm{~Hz}$ em todos os tempos avaliados para as preparações contendo pancurônio e rocurônio Conclusion: A freqüência de estímulo interfere significativamente na instalação do bloquio neuromuscular produzido por pancurônio e rocurônio, uma vez que a redução na amplitude da resposta do diafragma foi maior para a freqüência de $1 \mathrm{~Hz}$ em todos os períodos estudados.

Descritores: Agentes não Despolarizantes Neuromusculares. Bloqueadores neuromusculares. Nervo Frênico. Diafragma. Estimulação Elétrica. Ratos. 


\section{Introduction}

The onset of action, degree of neuromuscular blockade and duration of action of nondepolarizing neuromuscular blocking drugs (NNMD) depend on a variety of factors. These include the cardiac output, circulation time to muscle, muscle blood flow, affinity for the site of action, potency and dose administered ${ }^{1}$. The influence of the stimulation mode, frequency and time interval between stimuli, as well as the stimulation period before administering the neuromuscular blocker, has been demonstrated both on the potency and onset times of these agents ${ }^{2-8}$. High-frequency stimulation, since it increases muscle blood flow, results in a stronger effect of neuromuscular blockers ${ }^{9,10}$. Our aim was to compare the influence of two stimulation frequencies on the installation of the neuromuscular blocked produced by pancuronium and rocuronium on the rat diaphragm.

\section{Methods}

The protocol $n^{\circ} 883-1$, is in agreement with the Ethical Principles for Animal Research established by Brazilian College for Animal Experimentation (COBEA) and was approved by the institutional Committee for Ethics in Animal Research (State University of Campinas - UNICAMP) on september 13, 2005. Male Wistar rats weighing 250-300 $\mathrm{g}$, were housed in groups of 5 per cage with free access to food and water in a temperature controlled room (23 $\pm 1^{\circ} \mathrm{C}$ ) with a 12-h lightdark cycle (lights on at 6:00 am). Experiment was performed using a rat anesthetized with urethane and sacrificed by exsanguination. The hemidiaphragm was mounted essentially as described by Bulbring ${ }^{11}$. The preparation was suspended under a constant tension of $5 \mathrm{~g}$ in a $40 \mathrm{ml}$ organ bath containing aerated $\left(95 \% \mathrm{O}_{2}-5 \% \mathrm{CO}_{2}\right)$ Tyrode solution $\left(\mathrm{pH} 7.4,37^{\circ} \mathrm{C}\right)$ of the following composition (mM): $\mathrm{NaCl} 137, \mathrm{KCl} 2.7$, $\mathrm{CaCl}_{2}$ 1.8, $\mathrm{MgCl}_{2}$ 0.49, $\mathrm{NaH}_{2} \mathrm{PO}_{4} 0.42, \mathrm{NaHCO}_{3} 11.9$ and glucose 11.1. The nerve was placed over platinum probes connected to a Grass S48 stimulator. The diaphragm was held by its tendinous portion under constant tension through a wire connected to a Load Cell BG50 GMS isometric transducer. The diaphragm was submitted to an indirect stimulation frequency of 0.1 to $1 \mathrm{~Hz}$ lasting $0.2 \mathrm{msec}$ (Groups I and II, respectively) and the tension variations produced by diaphragmatic contractions were recorded by a Gould RS 3400 physiographer. The preparations were allowed to stabilize for at least $20 \mathrm{~min}$ before drug addition. Subgroups $\mathrm{P}$ and $\mathrm{R}(\mathrm{n}=5)$ were formed according to the neuromuscular blocker employed (pancuronium - $2 \mu \mathrm{g} / \mathrm{mL}$ and rocuronium - $4 \mu \mathrm{g} / \mathrm{mL}$, respectively). The installation of neuromuscular blockade was evaluated at 5, 15 and 30 minutes after addition of the neuromuscular blocker. Results were expressed as the mean \pm SEM. For statistical analysis, the multivariate analysis of variance (MANOVA) was the method used for repeated measurements. The assumed normality required by the method was achieved by the Box-Cox transformation. The model compared the percentages of twitch reduction between groups I and II $(0.1 \mathrm{~Hz}$ and $1 \mathrm{~Hz})$ and with time in both subgroups (subgroup $\mathrm{R}$ - rocuronium and subgroup $\mathrm{P}$ - pancuronium), adopting a significance level of $1 \%(\mathrm{p}<0.01)$.

\section{Results}

Twenty rats were used in this series of experiments from which hemidiaphragms were extracted. After obtaining the control muscle response with different stimulation frequencies $(0.1 \mathrm{~Hz}$ and $1 \mathrm{~Hz})$ and the addition of neuromuscular blockers (rocuronium and pancuronium), neuromuscular blockade was recorded and analysed. In both groups (Group I - 0.1Hz and Group II -1Hz) and subgroups $\mathrm{R}$ (rocuronium) and $\mathrm{P}$ (pancuronium), an increase in the percentages of the reduction in twitch height was observed (Figures 1 and 2), with a significant difference between the different times studied, compared to the control muscle's response. The effect of increasing stimulation frequency on the installation of neuromuscular blockade was statistically significant for both drugs $(\mathrm{p}<0.01)$. For both subgroups, mean values of the percentages of the reduction in twitch height between both groups in the different times studied were compared and also showed a statistically significant difference. For both drugs, the reduction in twitch height in Group II is greater than in Group I at all times studied $(\mathrm{p}<0.01)$. MANOVA confirmed a difference between groups I and II $(\mathrm{p}<0.01)$, with a significant increase in the percentage of twitch reduction with time $(p<0.01)$.

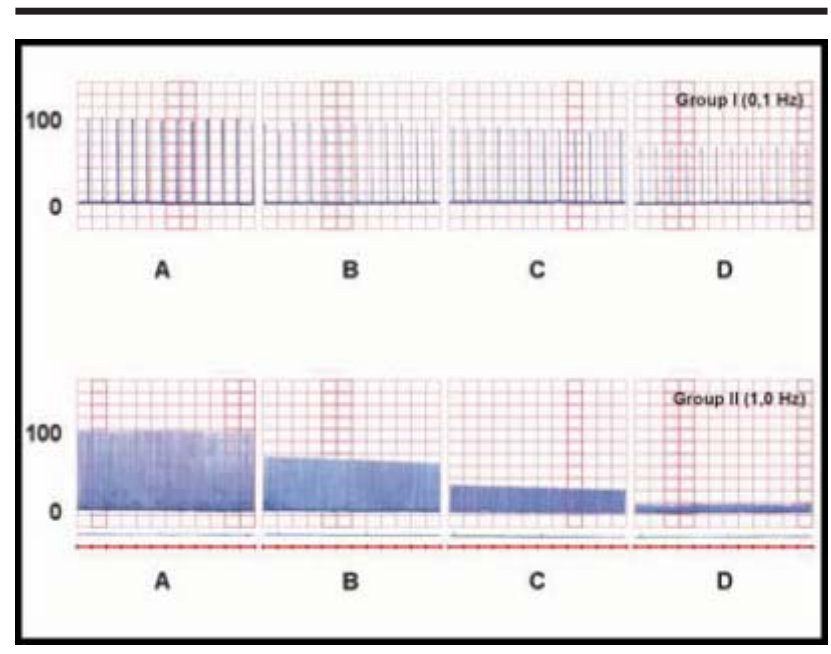

FIGURE 1 - Subgroup R (rocuronium $4 \mu \mathrm{g} / \mathrm{ml}$ )- The diaphragm's response to indirect stimulation: upper trace (Group I-0.1 Hz); lower trace (Group II-1 Hz) control-stabilization period of muscle response (A); 5 (B); 15 (C) and 30 minutes (D) after administering the neuromuscular blocker 


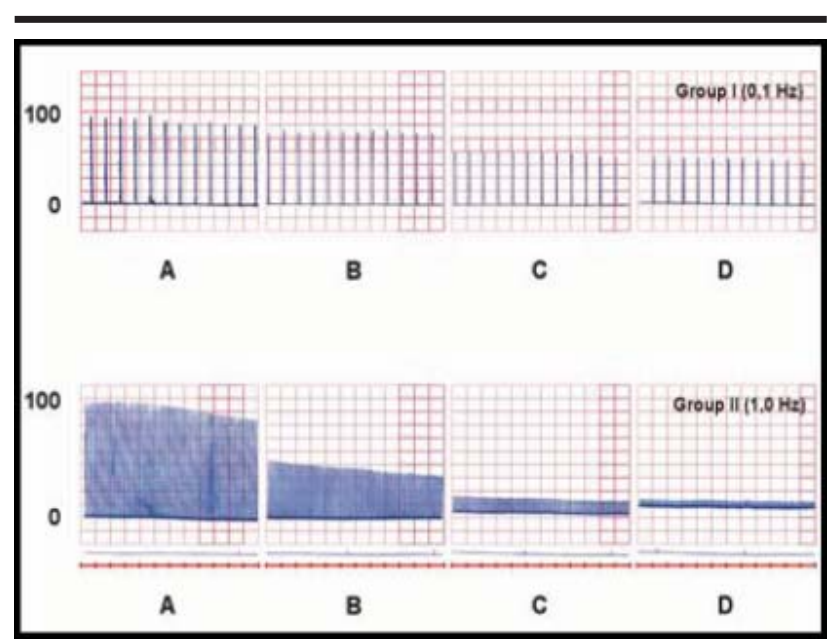

FIGURE 2 - Subgroup P (pancuronium $2 \mu \mathrm{g} / \mathrm{ml}$ )-The diaphragm's response to indirect stimulation: upper trace (Group I-0.1 Hz); lower trace (Group II-1 Hz) control-stabilization period of muscle response (A); 5 (B); 15 (C) and 30 minutes (D) after administering the neuromuscular blocker
Mean values and standard deviations of the percentage of height reduction in diaphragm response are shown in Tables 1 and 2. The experiments were conducted on rat diaphragms to determine the effect of different stimulation frequencies on the evolution of the neuromuscular blockade produced by pancuronium and rocuronium, steroidal neuromuscular blockers used routinely in clinical practice. Rocuronium is an aminosteroid with an intermediate duration of action, resulting from structural modifications in the vecuronium molecule. These modifications resulted in a less potent compound (ED50=144,8 $\mu \mathrm{g} \cdot \mathrm{kg}^{-1}$ and ED95 $=322 \mu \mathrm{g} \cdot \mathrm{kg}^{-1}$ ), having approximately one-sixth the potency of its analogue and a more rapid onset than other agents available in clinic $^{12,13}$. Pancuronium, a long-acting aminosteroid $\quad\left(\mathrm{ED} 50=32,4 \mu \mathrm{g} \cdot \mathrm{kg}^{-1}\right.$ and $\mathrm{ED} 95=58,1 \mu \mathrm{g}$. $\left.\mathrm{kg}^{-1}\right)$ is about 4,5 times more potent than rocuronium ${ }^{13}$.

TABLE 1 - Percentage of height reduction (\%) in the diaphragm response to indirect stimulation at different times studied - Group I $(0.1 \mathrm{~Hz})$ and Group II $(1 \mathrm{~Hz})$ : subgroup R (rocuronium)

\begin{tabular}{llllll}
\hline Subgroup & Group & 5 min & 15 min & 30 min & $\mathrm{p}$ \\
\hline Rocuronium & I & $4.66 \pm 0.71$ & $15.4 \pm 0.96$ & $33.5 \pm 1.13$ & $<0.01^{*}$ \\
& II & $40.14 \pm 2.27$ & $68.7 \pm 3.31$ & $81.0 \pm 7.17$ & \\
\hline
\end{tabular}

Data are the mean $\pm \mathrm{SD} . *$ Significant difference $(\mathrm{p}<0.01)$ between the two stimulation frequencies

TABLE 2 - Percentage of height reduction (\%) in the diaphragm's response to indirect stimulation at different times studied - Group I $(0.1 \mathrm{~Hz})$ and Group II (1Hz): subgroup P (pancuronium)

\begin{tabular}{llllll}
\hline Subgroup & Group & $5 \mathrm{~min}$ & $15 \mathrm{~min}$ & $30 \mathrm{~min}$ & $\mathrm{p}$ \\
\hline Pancuronium & I & $8.37 \pm 0.63$ & $33.95 \pm 4.09$ & $43.8 \pm 1.07$ & $<0.01^{*}$ \\
& II & $56.86 \pm 4.50$ & $81.03 \pm 4.21$ & $96.3 \pm 1.51$ & \\
\hline
\end{tabular}

Data are the mean $\pm \mathrm{SD} .{ }^{*}$ Significant difference $(\mathrm{p}<0.01)$ between the two stimulation frequencies

\section{Discussion}

The influence that the time required for obtaining the control response and the stimulation frequency may have on the onset and degree of neuromuscular blockade b $^{3,7,14}$ is currently debated. Previous studies demonstrated that both the degree of blockade and the onset of action of neuromuscular blockers may be affected by a number of factors, such as the stimulation mode employed, these effects being more important when more rapid frequencies are used ${ }^{3-6,8}$. The successive contractions produced by highfrequency nerve stimulation increase metabolic activity and muscle blood flow, resulting in a greater supply of drug to the stimulated muscle $e^{7,10,15}$. Factors related to the type of monitor used also interfere in the onset time of blockade. The application of a preload to the adductor pollicis muscle, indispensable in mechanomyography, increases regional metabolism, leading to a greater blood supply to the monitored muscle. Consequently, a larger number of neuromuscular blocker molecules may reach the neuromuscular junction at a shorter time interval ${ }^{1,3,15}$. Muscle blood flow is important because muscles close to the central circulation and with a better perfusion such as the diaphragm tend to be more rapidly paralyzed than peripheral and less perfused muscles such as the adductor pollicis $^{16,17}$. Another explanation is that more frequent stimulation may lead to neurotransmitter depletion at the stimulation site, causing a greater and earlier blockade of muscle response $e^{7,14,18}$. Indeed, if the number of acetylcholine molecules is decreased, the proportion of receptors which 
need to be occupied by the relaxant to inhibit neuromuscular transmission will be reached more rapidly ${ }^{7,14}$. The present study demonstrated that the percentages of height reduction in muscle response produced by the two neuromuscular blockers are significantly increased when high-frequency stimulation $(1 \mathrm{~Hz})$ is applied. These results emphasize the need to be judicious when comparing the onset time and degree of neuromuscular blockade in studies with different frequencies and modes of stimulation. An effect not evidenced when the motor nerve is stimulated with a $0.1 \mathrm{~Hz}$ frequency may be partially revealed with $2 \mathrm{~Hz}$ frequencies and totally revealed when high-frequency stimulation is applied ${ }^{19}$. In addition, the difference in sensitivity between the diverse muscle groups must be considered and varies according to the drug used and the type of muscle fiber, i.e., it depends on physiologic and histologic differences between muscles ${ }^{20,21}$. It is accepted that red fibers or slowtwitch muscles, are more sensitive to nondepolarizing neuromuscular blockers than fast-twitch white fibers. The adductor pollicis is made up of slow-twitch fibers and the diaphragm is made up of red fibers ${ }^{22}$. The presence of a larger number of cholinergic receptors at the motor end-plate of fast-twitch fibers in comparison to slowtwitch fibers may also explain the difference in sensitivity between both types of muscle fibers ${ }^{20}$. In clinical practice it is very important to reduce the time between the induction of anesthesia and tracheal intubation, which is a period a greater risk for hipoxia and aspiration of gastric contents. Considering circulation time for laryngeal and respiratory muscles, onset of neuromuscular blockade is faster in these muscles than in the pollicis adductor which is frequently used in clinical practice for monitoring neuromuscular function ${ }^{16,23}$. Since the adductor pollicis is more suitable for use in routine clinical practice, the use of a stimulation frequency of $1 \mathrm{~Hz}$ is recommended to determine the time corresponding to optimal intubating conditions ${ }^{(24)}$. Previous clinical studies found a reduction of about $50 \%$ in the onset time of rocuronium when stimulation frequency was increased from $0.1 \mathrm{~Hz}$ to $1 \mathrm{~Hz}$ and associated this shortened onset with rocuronium's probable presynaptic effect. The early occupation of prejunctional cholinergic receptors interferes with the mobilization of acetylcholine from reserve storage vesicles to readily available stores. Thus, there is a decrease in acetylcholine release according to an increasing rate of stimulation ${ }^{19}$. Factors related to the drug may interfere in the supply of a sufficient amount of drug molecules to occupy a certain number of cholinergic receptors, reduce the margin of safety and compromise the integrity of the neuromuscular junction. Drug affinity for the neuromuscular junction, as well as the potency, clearance and dose of drug administered are emphasized ${ }^{19,24}$. In this study, subparalyzing doses of rocuronium and pancuronium were used and the evolution of the blockade occurred in a differentiated manner for two neuromuscular blockers. The percentages of decrease in muscle response obtained with pancuronium at the different times studied in both groups $(0,1$ and $1 \mathrm{~Hz})$, were greater than that observed with rocuronium, under the same conditions, which may be attributed to pancuronium's greater potency in comparison to rocuronium. However, there is evidence that onset of neuromuscular blocked is more dependent on patient characteristics than on the properties of the muscle relaxants ${ }^{1}$.

\section{Conclusion}

Our results demonstrate a difference in response to the blockers used, as the stimulation frequency is increased. The decrease in of neuromuscular responses on the rat diaphragm produced by the two agents is greater when high frequencies are used.

\section{References}

1. Donati F. Onset of action of relaxants. Can J Anaesth. 1988; 35: 52-8.

2. Ali HH, Savarese JJ. Stimulus frequency and dose-response curve to d-tubocurarine in man. Anesthesiology. 1980; 52: 36-9.

3. Cuuran MJ, Donati F, Bevan DR. Onset and recovery of atracurium and suxamethonium-induced neuromuscular blockade with simultaneous train-of-four and single twitch stimulation. Br J Anaesth. 1987; 59: 989-94.

4. Bell PF, Gibson FM, Mirakhur RK, Clarke, RSJ. Comparison of single twitch and train-of-four modes of stimulation for measurement of nondepolarizing neuromuscular block. Br J Anaesth. 1988; 60: 343.

5. Cooper RA, Mirakhur RK, Elliot P, McCarthy GJ. Estimation of the potency of ORG 9426 using two different modes of nerve stimulation. Can J Anaesth. 1992; 39: 139-42.

6. Maddineni VR, Mirakhur RK, Cooper R. McCoy E. Potency estimation of mivacurium: comparison of two different modes of nerve stimulation. $\mathrm{Br} \mathrm{J}$ Anaesth. 1993; 70: 694-5.

7. McCoy EP, Mirakhur RK, Connoly FM, Loan PB. The influence of the duration of control stimulation on the onset and recovery of neuromuscular block. Anesth Analg. 1995; 80:364-7.

8. Viby-Mogensen J, EngbaekJ, Eriksson LI. Good Clinical Research Practice (GCRP) in pharmacodynamic studies of neuromuscular blocking agents. Acta Anaesthesiol Scand. 1996; 40: 59-74.

9. Preston JB, Van Maanen EF. Effects of frequency of stimulation on the paralyzing dose of neuromuscular blocking agents. J Pharmacol Exp Ther. 1953; 107: 165-71. 
10. Goat VA, Yeung ML, Blakeney C, Feldman, SA. The effect of blood flow upon the activity of gallamine triethiodide. Br J Anaesth. 1976; 48: 69-73.

11. Bulbring E. Observations on the isolated phrenic nerve-diaphragm preparation on the rat. Br J Anaesth. 1946;1:38-61.

12. Wierda JMKH, De Wit APM, Kuizenga K. Clinical observations on the neuromuscular blocking action of ORG 9426, a new steroidal non-depolarizing agent. Br J Anaesth; 1990; 64: 521-3.

13. Naguib M, SamarkandiAH, Bakhames HS. Comparative potency of steroidal neuromuscular blocking drugs and isobolographic analysis of the interaction between rocuronium and other aminosteroids. $\mathrm{Br} \mathrm{J}$ Anaesth. 1995; 75:37-42.

14. Girling KJ, Mahajan RP. The effect of stabilization on the onset of neuromuscular block when assessed using accelerometry. Anesth Analg. 1996; 82: 1257-60.

15. Saxena PR, Dhasmana KM, Prakash O. A comparison of systemic and regional haemodynamic effects of d-tubocurarine, pancuronium and vecuronium. Anesthesiology. 1983; 59: 102-08.

16. Chauvin M, Lebreault C, Duvaldestin P. The neuromuscular blocking effect of vecuronium on the human diaphragm. Anesth Analg. 1987; 66: 117-22.
17. Pansard JL, Chauvin M, Lebreault C, Gauneau P, Duvaldestin P. Effect of an intubating dose of succinylcholine and atracurium on the diaphragm and adductor pollicis in humans. Anesthesiology. 1987; 67:326-30.

18. Galindo A. Procaine, pentobarbital and halothane: effects at the mammalian myoneural junction. J Pharmacol Exp Ther. 1971; 177: 360-8.

19. Feldman SA, Khaw K. The effect of dose and the rate of stimulation on the action of rocuronium. Eur J Anaesth. 1995; 12: 15-7.

20. Sterz R, Pagala M, Peper K. Postjunctional characteristics of the endplates in mammalian fast and slow muscles. Pflugers Arch. 1983; 398: 48-54.

21. Ibebunjo C, Srikant CB, Donati F. Properties if fibres, endplates and acetylcholine receptors in the diaphragm, masseter, laryngeal, abdominal and limb muscles in the goat. Can J Anaesth. 1996; 43: 475-84.

22. Smith CE, Donati F, Bevan DR. Differential effects of pancuronium on masseter and adductor pollicis muscles in humans. Anesthesiology. 1989; 71: 57-61.

23. Donati F, Meistelman C, Plaud B. Vecuronium neuromuscular blockade at adductor pollicis. Anesthesiology. 1991; 74:833-7.

24. DeMeyJC,DeLaat.Factorsinfluencingtheprofileofonset of relaxation. Acta Anaesthesiol Belg. 1997; 48: 7-10.

\section{Correspondence:}

Angélica de Fátima de Assunção Braga

R. Luciano Venere Decourt, 245

13084-040 Campinas - SP Brazil

Phone: (55 19)3289-5092

franklinbraga@terra.com.br
Conflict of interest: none

Financial source: none

Received: April 18, 2007

Review: June 20, 2007

Accepted: July 19, 2007

\section{How to cite this article}

Braga AFA, Munoz DC, Braga FSS, Araújo DR, Potério GMB, Mantovani M. Influence of stimulus frequency on blockade induced by pancuronium and rocuronium. Study on rats phrenic nerve-diaphragm preparation. Acta Cir Bras. [serial on the Internet] 2007 Nov-Dec;22(6). Available from URL: $\underline{\text { http://www.scielo.br/acb }}$ 